\title{
ANALISIS PEMAHAMAN KONSEP ALJABAR PADA MATA KULIAH ALJABAR LINEAR ELEMENTER
}

\section{ANALYSIS OF CONCEPT UNDERSTANDING IN ELEMENTARY LINEAR ALGEBRA}

\author{
Adila Mufidah B1), Sri Sulasteri2), Ahmad Farham Majid'3), Lisnasari Andi Mattoliang4) \\ 1,2,3,4)Fakultas Tarbiyah dan Keguruan Universitas Islam Negeri Alauddin Makassar

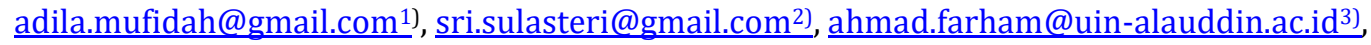 \\ lisnasari.mattoliang@uin-alauddin.ac.id ${ }^{4)}$
}

\begin{abstract}
Abstrak
Artikel ini bertujuan untuk mengetahui kemampuan pemahaman konsep mahasiswa berdasarkan indikator pemahaman matematis pada mata kuliah aljabar linear elementer materi ruang vektor, sub ruang vektor, dan vektor Euclidean. Penelitian ini menggunakan pendekatan deskriptif kualitatif. Subjek penelitian meliputi mahasiswa jurusan pendidikan matematika fakultas tarbiyah dan keguruan UIN Alauddin Makassar angkatan 2016 yang diduga mengalami kesulitan dalam memahami konsep pada mata kuliah aljabar linear elementer. Instrumen penelitian yang digunakan adalah tes diagnostik dan wawancara. Teknik analisis data yaitu reduksi data, penyajian data, dan penarikan kesimpulan. Hasil penelitian menunjukkan bahwa kemampuan pemahaman mahasiswa jurusan pendidikan matematika UIN Alauddin Makassar angkatan 2016 dalam menyelesaikan soal aljabar linear elementer ditinjau dari indikator kemampuan pemahaman matematis, mahasiswa tergolong cukup mampu pada indikator: (1) pemahaman mampu menyatakan ulang sebuah konsep, (2) menyajikan konsep dalam berbagai bentuk representasi matematika, (3) menggunakan, memanfaatkan dan memilih prosedur tertentu, dan (4) mengaplikasikan konsep/algoritma ke pemecahan masalah. Namun, mahasiswa tergolong tidak mampu pada indikator kemampuan memberi contoh dan bukan contoh.
\end{abstract}

Kata Kunci: pemahaman konsep, aljabar linear elementer, matematika

\begin{abstract}
This article aims to determine the ability to understand student concepts based on indicators of mathematical understanding in elementary linear algebra courses in vector space, sub vector spaces, and euclidean vectors. This research used desciptive qualitative approach. Research subjects included students majoring in mathematics education at the tarbiyah faculty and the UIN Alauddin Makassar class of 2016 who were suspected of having difficulty understanding concepts in linear elementary algebra courses. The research instruments used were diagnostic tests and interviews. Data analysis techniques are data reduction, data presentation, and drawing conclusions. The results showed that the understanding ability of students majoring in mathematics education at UIN Alauddin Makassar class of 2016 in solving linear elementary algebra in terms of indicators of mathematical understanding ability, students classified as quite capable of indicators: (1) understanding is able to restate a concept, (2) present the concept in various forms of mathematical representation, (3) using, utilizing and choosing certain procedures, and (4) applying concepts / algorithms to problem solving. However, students are classified as not capable of the ability to set examples and not examples.
\end{abstract}

Keywords: concept understanding, elementary linear algebra, mathematics 
How to Cite: Mufidah, A., Sulasteri, S., Majid, A.F., \& Mattoliang, L.A. (2019). Analisis pemahaman konsep aljabar pada mata kuliah aljabar linear elementer. Al-Asma: Journal of Islamic Education, 1(1), 42-51.

\section{PENDAHULUAN}

Pendidikan merupakan salah satu usaha yang ditempuh dalam rangka mencerdaskan kehidupan bangsa. Dalam pelaksanaan pendidikan terdapat proses pembelajaran yang setiap jenjangnya, peserta didik dituntut untuk mengikuti mata pelajaran tertentu, termasuk mata pelajaran matematika (Nursuprianah \& Sholikhah, 2009). Matematika timbul karena pikiran-pikiran manusia yang berhubungan dengan ide, proses dan penalaran.

Matematika pada hakekatnya merupakan aktivitas mental yang tinggi untuk memahami arti struktur-struktur, hubungan-hubungan, simbol-simbol, keabstrakan, yang kemudian menerapkannya dalam situasi nyata. Jadi belajar matematika merupakan suatu proses aktif yang sengaja dilakukan untuk memperoleh pengetahuan yang dapat mengakibatkan terjadinya perubahan tingkah laku (Sanuartini, 2000). Dengan demikian, untuk mencapai pemahaman tentang suatu materi matematika membutuhkan fondasi yang kuat, yaitu dengan memahami konsep yang merupakan prasyarat yang utama.Hal ini melingkupi penalaran, konsep pemahaman simbol, dan penguasaan konsep keabstrakan dan generalisasi.Walaupun pada kenyataannya, adanya perbedaan kemampuan dalam memahami materi matematika ini.

Pembelajaran matematika khususnya di dunia pendidikan sering ditemukan kendala dalam proses belajar mengajar. Fakta telah menunjukkan bahwa matematika adalah pelajaran yang menakutkan dan menegangkan sehingga sebagian besar siswa menganggapnya sebagai momok di sekolah. Prestasi belajar matematika cenderung lebih rendah bila dibandingkan dengan materi pembelajaran yang lain. Hal ini disebabkan karena sebagian siswa memiliki persepsi bahwa pelajaran matematika itu sulit dipelajari, kurang menyenangkan, dan sulit untuk menghafal rumus-rumus matematika. Berdasarkan pernyataan tersebut dapat disimpulkan bahwa terdapat beberapa kendala dalam proses pembelajaran matematika sehingga prestasi belajar matematika cenderung lebih rendah jika dibandingkan dengan materi pembelajaran yang lain, salah satu kendalanya yaitu kurangnya pemahaman peserta didik mengenai konsep matematika.

Matematika merupakan pelajaran yang dipelajari mulai dari bangku sekolah dasar hingga bangku perguruan tinggi. Matematika di jenjang Perguruan Tinggi (PT) sangatlah berbeda dengan matematika pada jenjang lainnya. Karena menurut Ruseffendi bahwa matematika di PT mencakup 4 wawasan yang luas yaitu aritmatika, aljabar, geometri dan analisis. Maka dari itu, pembelajaran matematika di perguruan tinggi menuntut peserta didik untuk lebih berpikir rasional dibandingkan dengan pembelajaran matematika yang diperoleh sebelumnya di sekolah-sekolah (Nursuprianah \& Sholikhah, 2009).

Pemahaman pada dasarnya berasal dari kata "paham" yang mengandung makna "benar-benar mengerti". Seorang peserta didik dikatakan memahami sesuatu apabila ia dapat memberikan penjelasan atau memberi uraian lebih rinci tentang hal itu dengan menggunakan kata-kata sendiri (Sudijono, 2009). Skemp membagi pemahaman menjadi dua yaitu pemahaman instrumental dan pemahaman relasional. Pemahaman instrumental mengarahkan mahasiswa untuk menghasilkan jawaban yang benar karena jenis 
pemahaman ini menuntut mahasiswa untuk berpikir secara prosedural atau algoritmik (Sumarmo, 2006). Mahasiswa biasanya dihadapkan hanya pada persolan rutin sehingga biasanya mahasiswa memiliki kemampuan koneksi yang sangat rendah dan terbatas. Pada umumnya mereka akan kesulitan mengadaptasi suatu permasalahan yang tidak rutin dengan skema yang sudah ada dalam struktur mentalnya. Pemahaman jenis relasional mengarahkan mahasiswa untuk mengaitkan konsep dalam satu topik maupun mengaitkan konsep antar topik. Mahasiswa yang memiliki kemampuan relasional dapat membangun koneksi yang lebih luas untuk membuat conceptual framework sehingga dapat membantu mereka dalam mengaplikasikan konsep matematis. Oleh karena itu, karena pentingnya kedua jenis kemampuan pemahaman tersebut, dalam penelitian ini kemampuan pemahaman matematis yang diteliti dibatasi pada kemampuan instrumental dan relasional.

Salah satu materi yang penting dan mendasar dalam matematika adalah aljabar. Hal ini dikarenakan aljabar merupakan cabang matematika yang dicirikan sebagai generalisasi dari bidang aritmetika, dan aritmatika merupakan salah satu pondasi dasar matematika. Pemahaman konsep aljabar merupakan salah satu kecakapan atau kemahiran aljabar yang diharapkan dapat tercapai dalam pembelajaran matematika melalui penunjukan keterkaitan antarkonsep dan aplikasi konsep atau algoritma secara luwes, akurat, efisien, dan tepat dalam pemecahan masalah. Derajat pemahaman konsep ditentukan oleh tingkat keterkaitan antara gagasan, prosedur, dan pemecahan masalah. Sehubungan dengan hal tersebut, maka pemahaman konsep merupakan kompetensi yang dimiliki mahasiswa dengan beberapa indikator berikut: (1) menyatakan atau menjelaskan ulang sebuah konsep; (2) mengklasifikasikan sifat-sifat tertentu; (3) memberi contoh; (4) merepresentasikan konsep; (5) menggunakan konsep untuk menyelesaikan masalah (Darminto, 2009). Dalam Aljabar memiliki pokok permasalahan untuk dikembangkan lebih lanjut lagi, salah satunya yaitu Aljabar Linear.

Aljabar Linier Elementer merupakan salah satu mata kuliah dasar yang diberikan sebelum mengambil mata kuliah matematika tingkat lanjut dan setelah mahasiswa mengambil mata kuliah Kalkulus.Mata kuliah ini menuntut mahasiswa untuk berpikir cermat dan teliti. Beberapa materi yang dipelajari pada mata kuliah Aljabar Linear Elementer antara lain adalah matriks, sistem persamaan linear dan determinan dengan masing-masing mempunyai kesulitan yang berbeda-beda dan saling berkaitan satu sama lain (Fitria, Arnawa, \& Lufri, 2014). Kompetensi yang harus dikuasai mahasiswa ketika belajar materi matriks, sistem persamaan linear dan determinan adalah mahasiswa dapat menguasai sistem persamaan linier beserta dengan cara memecahkannya serta sifatsifatnya, memahami matriks dan operasi yang ada pada matriks dan mahasiswa mampu untuk mencari invers suatu matriks. Selain itu, mahasiswa juga dapat menguasai sifat-sifat fungsi determinan dan dapat mencari determinan suatu matriks bujur sangkar.

Berdasarkan observasi yang dilakukan pada tanggal 13 Maret 2017 melalui wawancara dengan 5 mahasiswa pendidikan matematika UIN Alauddin Makassar angkatan 2016 yang telah mengikuti mata kuliah Aljabar Linear Elementer pada semester III, 2 diantaranya berpendapat mata kuliah ini tidak terlalu sulit karena sebagian materinya membahas SPL, matriks, determinan dan vektor yang telah dipelajari sebelumnya di bangku sekolah. Sedangkan 3 diantaranya berpendapat mata kuliah ini sulit karena mereka kurang memahami konsep-konsep dasar yang digunakan dalam 
materi kuliah ini sehingga cenderung mengalami kesulitan dalam menyelesaikan soal mata kuliah aljabar linear elementer.

Berdasarkan penelitian yang telah dilakukan oleh Cita Dwi Rosita dkk, yang berjudul "Analisis Kemampuan Pemahaman Matematis Mahasiswa pada Mata Kuliah Aljabar Linear 1" (Rosita, Laelasari, \& Noto, 2014) menyimpulkan bahwa ketercapaian pada setiap indikator soal TKPM, hanya 3 indikator mencapai lebih dari atau sama dengan $70 \%$, sedangkan 4 indikator lainnya kurang dari 70\% dengan terendah ketercapaian 50\%, kemampuan pemahaman matematis mahasiswa secara klasikal tidak mencapai ketuntasan artinya nilai rata-rata semua mahasiswa berada di bawah KKM yang ditentukan yaitu 65. Ketuntasan kemampuan pemahaman matematis mahasiswa secara individual disimpulkan bahwa terdapat nilai TKPM mahasiswa yang mencapai lebih atau sama dengan 65 sebanyak 54,38\% dari keseluruhan mahasiswa, adanya perbedaan ketuntasan pada kelompok mahasiswa berdasarkan tingkat kemampuan tinggi, sedang dan rendah di mana masing-masing memperoleh rata-rata 84,7714; 65,7500; 47,1395. Mahasiswa dengan tingkat kemampuan tinggi dan sedang mencapai ketuntasan lebih dari 65 , sedangkan untuk yang berkemampuan rendah belum tuntas.

Dari uraian tersebut, peneliti berkeinginan untuk melakukan penelitian yang berkaitan dengan pemahaman konsep aljabar pada mata kuliah aljabar linear elementer mahasiswa pendidikan matematika uin alauddin makassar angkatan 2016. Dengan demikian, penelitian ini bertujuan untuk menganalisis pemahaman konsep aljabar pada mata kuliah Aljabar Linear Elementer mahasiswa pendidikan matematika UIN Alauddin Makassar angkatan 2016 berdasarkan indikator kemampuan pemahaman matematis pada ruang vektor, subruang vektor, dan ruang vektor Euclidean serta faktor-faktor yang mempengaruhinya.

\section{METODE PENELITIAN}

Penelitian ini adalah penelitian deskriptif kualitatif. Sumber data adalah subjek penelitian, dalam hal ini mahasiswa jurusan pendidikan matematika angkatan 2016. Untuk memeriksa keabsahan data penelitian, peneliti menggunakan triangulasi teknik dengan cara memeriksa data kepada subjek yang sama dengan teknik berbeda yakni tes diagnostik dan wawancara (Sugiyono, 2013). Tes diagnostik terdiri atas 7 soal uraian materi ruang vektor, subruang vektor, dan ruang vektor Euclidean. Data kemampuan pemahaman konsep matematika mahasiswa diperoleh dengan memeriksa lembar jawaban tes sesuai dengan rubrik penskoran. Kemudian data tersebut dianalisis secara deskriptif kuantitatif untuk melihat pencapaian kemampuan pemahaman konsep matematika mahasiswa dalam proses perkuliahan. Rata-rata nilai akhir yang diperoleh digunakan untuk melihat kategori kemampuan pemahaman konsep matematika mahasiswa. Adapun wawancara dilakukan secara lisan kepada mahasiswa dengan tingkat kemampuan berbeda. Data hasil wawancara dianalisis secara deskriptif kualitatif dan digunakan sebagai data pendukung hasil tes kemampuan pemahaman konsep matematika mahasiswa. Analisis data dilakukan melalui tahap reduksi data, penyajian data, dan penarikan kesimpulan. 


\section{HASIL DAN PEMBAHASAN \\ Hasil Penelitian}

Berdasarkan hasil final mahasiswa dalam mengerjakan soal aljabar linear elementer materi ruang vektor, sub ruang vektor dan ruang vektor Euclidean, ditemukan bagaimana kemampuan pemahaman konsep matematis mahasiswa. Berdasarkan penilaian hasil kerja mahasiswa dan untuk mengetahui lebih jauh tentang faktor-faktor yang mempengaruhi kemampuan pemahaman tersebut, maka peneliti memilih beberapa mahasiswa untuk dianalisis jawabannya. Pemilihan mahasiswa ini dilakukan dengan pertimbangan bahwa beberapa mahasiswa tersebut memperoleh nilai yang tinggi, sedang dan rendah dalam mengerjakan soal terkait dengan pemahaman konsep ruang vektor, sub ruang vektor dan vektor euclidean. Berikut hasil analisis pengkategorian keseluruhan dan persentase ketercapaiannya.

Tabel 1. Deskripsi Kemampuan Pemahaman Keseluruhan

\begin{tabular}{clccc}
\hline No. & \multicolumn{1}{c}{ Indikator Pemahaman Konsep } & $\begin{array}{c}\text { Rata- } \\
\text { rata }\end{array}$ & $\begin{array}{c}\text { Skor } \\
\text { Maksimal }\end{array}$ & $\begin{array}{c}\mathbf{( \% )} \\
\text { Ketercapaian }\end{array}$ \\
\hline 1 & $\begin{array}{l}\text { Kemampuan menyatakan ulang sebuah } \\
\text { konsep }\end{array}$ & 11,40 & 20 & $57 \%$ \\
2 & $\begin{array}{l}\text { Kemampuan memberi contoh dan bukan } \\
\text { contoh }\end{array}$ & 1,70 & 20 & $8,5 \%$ \\
3 & $\begin{array}{l}\text { Kemampuan menyajikan konsep dalam } \\
\text { berbagai bentuk representasi matematika }\end{array}$ & 8,5 & 20 & $42,5 \%$ \\
4 & $\begin{array}{l}\text { Kemampuan menggunakan, } \\
\text { memanfaatkan, dan memilih prosedur } \\
\text { tertentu }\end{array}$ & 9,95 & 20 & $49,75 \%$ \\
5 & $\begin{array}{l}\text { Kemampuan mengaplikasikan } \\
\text { konsep/algoritma ke pemecahan masalah }\end{array}$ & 6,6 & 20 & $33 \%$ \\
\hline
\end{tabular}

Selanjutnya kriteria yang digunakan untuk mengkategorikan mahasiswa ke dalam kategori yaitu berdasarkan pada 3 skala pembagian tingkatan (Arikunto dan Jabar, 2010), yaitu:

1. $68 \% \leq P \leq 100 \%$ dikategorikan mampu (tinggi)

2. $34 \% \leq P \leq 67 \%$ dikategorikan cukup mampu (sedang)

3. $0 \% \leq P \leq 33 \%$ dikategorikan tidak mampu (rendah)

Setelah melakukan tes diagnostik, rata-rata ketercapaian indikator secara keseluruhan sebesar 38\%. Mahasiswa tergolong cukup mampu pada indikator: (1) pemahaman mampu menyatakan ulang sebuah konsep, (2) menyajikan konsep dalam berbagai bentuk representasi matematika, (3) menggunakan, memanfaatkan dan memilih prosedur tertentu, dan (4) mengaplikasikan konsep/algoritma ke pemecahan masalah. Namun, mahasiswa tergolong tidak mampu pada indikator kemampuan memberi contoh dan bukan contoh. Hal tersebut berdasarkan hasil analisis data yang dilakukan secara keseluruhan, sehingga persentase ketercapaian mahasiswa berada pada kategori cukup mampu.

Beberapa mahasiswa kemudian dipilih untuk diwawancarai terkait hasil pengerjaan soalnya, dipilih 5 mahasiswa di antaranya yaitu Subjek 5 yang mewakili kategori tinggi, Subjek 12 dan Subjek 18 yang mewakili kategori sedang, Subjek 20 dan 
Subjek 24 yang mewakili kategori rendah nilainya terkait dengan pemahaman konsep ruang vektor, sub ruang vektor dan vektor Euclidean.

Selanjutnya, untuk menelusuri lebih dalam tentang kemampuan mahasiswa terkait dengan pemahaman konsep dan faktor-faktor yang mempengaruhi kemampuan pemahaman tersebut, maka dilakukan wawancara mendalam terhadap kelima mahasiswa yang terpilih. Data hasil wawancara kemudian dibandingkan dengan data hasil final mahasiswa (triangulasi data), dengan tujuan untuk mendapatkan data yang valid.

Berdasarkan hasil pengerjaan dan wawancara dengan mahasiswa S5, menurut jawaban kedua dari S5 (J2), dapat dikatakan bahwa S5 sudah bisa menyatakan ulang konsep terkait materi ruang vektor, sub ruang vektor dan vektor Euclidean. Berdasarkan (J4), S5 menunjukkan mampu menyajikan konsep dalam bentuk representasi matematis. Namun berdasarkan (J6) dan (J10), S5 mengaku masih ada kendala memilih atau menentukan prosedur untuk menyelesaikan soal/permasalahan seperti halnya dalam memahami konsep seperti aksioma dalam mengerjakan soal pembuktian dengan alasan prosedurnya yang terlalu panjang dan masih bingung dalam menggunakan variabel atau konstanta dalam memberi contoh. Selain itu, masih ada sebagian konsep yang digunakan dalam mengerjakan soal hanya berdasarkan dugaan, bukan karena benar-benar paham dengan konsep.

Berdasarkan petikan wawancara di atas juga diperoleh faktor-faktor yang mempengaruhi kemampuan pemahaman S5 yang dapat disimpulkan dari jawaban subjek pada (J7), (J8), dan (J9), di mana peneliti menyimpulkan bahwa intensitas belajar merupakan faktor yang mempengaruhi kemampuan pemahaman. Sedangkan faktor lainnya terdapat pada (J10), di mana S5 tidak memahami konsep aksioma ruang vektor dikarenakan prosedur yang terlalu panjang.

Berdasarkan hasil pengerjaan dan petikan wawancara dengan mahasiswa S12 di atas, dari jawaban (J1), (J2), dan (J3), subjek mengaku mengetahui konsep namun masih bingung dalam menentukan prosedur untuk menyelesaikan soal. Dapat dikatakan bahwa mahasiswa masih keliru dalam menentukan cara menjawab soal, belum bisa menggunakan prosedur dengan sistematis, tidak mampu memberi contoh dari suatu konsep.

Berdasarkan petikan wawancara di atas, adapun faktor-faktor yang mempengaruhi kemampuan pemahaman S12, antara lain: berdasarkan jawaban (J4) dan (J5), S12 belajar hanya pada saat menjelang ujian dan hanya mempelajari konsep tanpa latihan mengerjakan soal yang berkaitan, sehingga S12 memahami hanya sebagian dari konsep, hal ini menyebabkan S12 tidak bisa menyelesaikan satu soal/permasalahan meskipun sebenarnya tahu konsepnya. Selain itu, berdasarkan jawaban subjek pada (J6), S12 jarang memperhatikan saat dosen menjelaskan di kelas atau dapat dikatakan kurang berkonsentrasi saat pembelajaran berlangsung. Selain itu, S12 masih malu-malu untuk bertanya pada dosen dan lebih memilih bertanya pada teman apabila ada materi yang sulit dipahami (J8). Pada (J9) dan (J10), S12 merasa kesulitan memahami konsep aksioma dengan alas an prosedur yang terlalu panjang dan rumit.

Berdasarkan hasil pengerjaan dan petikan wawancara dengan mahasiswa S20 di atas, dari jawaban subjek pada (J1), (J1), (J1), dan (J1) dapat diketahui bahwa mahasiswa tidak paham dengan materi soal sehingga menyebabkan mahasiswa tidak menjawab sebagian besar soal yang diberikan dan kalau pun ada soal yang dijawab, itu hanya 
berdasarkan perkiraan subjek. Dengan demikian, S20 menunjukkan kemampuan pemahaman yang rendah (tidak mampu).

Berdasarkan petikan wawancara di atas, faktor-faktor yang mempengaruhi kemampuan pemahaman subjek tersebut antara lain: S20 kurang mempelajari materi karena terlanjur menganggap materinya susah (J7), tidak latihan mengerjakan soal yang berkaitan dengan materi (J8) , kurang memperhatikan dosen ketika proses pembelajaran dan lebih memilih bermain gadget/tidak konsentrasi (J9), malu bertanya pada dosen maupun temannya (J12), dan tidak memiliki buku pegangan sendiri sebagai sumber ajar yang lain (J13). Hal-hal tersebut yang menjadi pemicu rendahnya kemampuan pemahaman S20.

\section{Pembahasan}

Berdasarkan penelitian yang telah dilakukan pada mahasiswa jurusan pendidikan matematika angkatan 2016 melalui soal tes diagnostik yang terdiri 5 soal uraian aljabar linear elementer yang disusun berdasarkan materi ruang vektor, subruang vektir dan ruang vektor Euclidean dan tes wawancara dari beberapa mahasiswa yang nilai tertinggi, sedang dan rendah. Dari hasil analisis pengerjaan mahasiswa, peneliti mengkategorikan mahasiswa berdasarkan kategori mampu, cukup mampu, dan tidak mampu. Pertama, mahasiswa yang termasuk ke dalam kategori mampu yaitu mereka mengetahui konsep dan mengetahui terbentuknya konsep atau menyatakan ulang sesuai konsep dalam hal ini mereka mampu menyelesaikan soal-soal yang diberikan dan mengaplikasikan ke dalam tes/soal ujian yang diberikan. Mereka juga di kategorikan mampu karena mampu menyelesaikan sendiri ketika di tengah proses penyelesaian ada hal yang salah. Kedua, mahasiswa yang termasuk ke dalam kategori cukup mampu yaitu mereka yang mngetahui konsep tetapi tidak menyatakan ulang sesuai konsepnya atau mereka yang mengetahui seperti apa permasalahan pada soal-soal tetapi tidak dapat menyelesaikan ke dalam tes/soal ujian yang diberikan, hal ini senada dengan beberapa jawaban mahasiswa yang tidak dapat menyelesaikan soal yang diberikan tetapi mereka mengetahui seperti apa konsep yang akan digunakan. Ketiga, mahasiswa yang termasuk ke dalam kategori tidak mampu mereka yang tidak mengetahui seperti apa konsepnya dan tidak menyatakan ulang konsepnya atau tidak dapat menjawab tes/soal ujian yang diberikan serta tidak dapat menyelesaikannya, hal ini karena ada mahasiswa yang memang tidak memahamai seperti apa yang ditanyakan pada soal dengan alasan tidak pernah didapatkan sebelumnya dan mereka tidak dapat menyelesaikan dengan alasan sudah lupa seperti apa konsep yang akan digunakan untuk menyelesaikannya tes/soal ujian tersebut meskipun mereka memahami materi dalam tes/soal ujian yang diberikan.

Berdasarkan hasil wawancara pada beberapa mahasiswa melalui tes diagnostik yang mendapat nilai tinggi, sedang dan rendah ternyata pemahaman kemampuan matematis mahasiswa berada pada kategori kurang mampu yang menunjukkan bahwa mahasiswa mengetahui konsep tetapi tidak menyatakan ulang sesuai konsepnya atau mereka yang mengetahui seperti apa permasalahan pada soal-soal tetapi tidak dapat menyelesaikan ke dalam tes/soal ujian yang diberikan, hal ini senada dengan beberapa jawaban mahasiswa yang tidak dapat menyelesaikan soal yang diberikan tetapi mereka mengetahui seperti apa konsep yang akan digunakan. berada pada tingkatan pemahaman intruksional (intructional understanding) dimana menurut Skemp dalam Hadiwiyanti seseorang baru berada ditahap tahu atau hafal tetapi dia belum atau tidak tahu mengapa 
hal itu bisa dan dapat terjadi.Lebih lanjut, seseorang pada tahapan ini juga belum atau tidak bisa menerapkan hal tersebut pada keadaan baru yang berkaitan. Hal ini berarti seseorang dapat mengetahui konsep yang digunakan namun tidak mengetahui mengapa prosedur itu yang digunakan dan terkadang hanya menebak jawaban yang diperoleh (Hadiwiyanti, 2015). Hal inilah yang terjadi pada mahasiswa Jurusan PendidikanMatematika UIN Alauddin Makassar angkatan 2016. Ada beberapa mahasiswa tidak tahu mengapa konsep itu yang digunakan dalam menyelesaikan tes/soal ujian dan mahasiswa tersebuthanya menebak-nebak seperti apa konsep yang akan digunakan untuk menyelesaikan soal yang diberikan. Adapun gambaran pemahaman dan faktor-faktor yang mempengaruhi serta memperkuat alasan dari kesimpulan dari setiap subjek wawancara adalah tentang kurangnya pemahaman konsep mahasiswa tentang materi yang terkait adalah wawancara langsung yang dilakukan pada lima subjek yang pada hakikat nya dan secara keseluruhan baik dari hasil wawancara dari nilai tertinggi, sedang maupun rendah adalah mahasiswa ketika mendapatkan suatu masalah, sebenarnya bisa menyelesaikannya namun yang menjadi kendala saat proses pembelajaran berlangsung mahasiswa masih banyak yang kurang percaya diri untuk bertanya kepada dosennya sehingga saat diberikan suatu masalah yang terkait dengan materi dalam hal ini pemberian tes/soal ujian mahasiswa sudah bingung menjawab, padahal notabenenya soal tersebut mudah dipahami. Hal lain yang menjadi permasalahan kurangnya pemahaman konsep karena bayangan dari luar masih banyak yang mempengaruhi, seperti penggunaan gadget saat belajar dan sebagian besar saat belajar mahasiswa banyak yang kurang memperhatikan. Selain itu, kurang nya pengulangan materi yang terkait dirumah. Selain hal yang mendasar di atas yang mempengaruhi pemecahan masalah dari kemampuan pemahaman konsep matematis adalah pengetahuan awal, apresisasi matematika, dan kecerdasan logis matematis mahasiswa. Pengetahuan awal yang dimaksud adalah kemampuan pengetahuan mahasiswa dapat membantu mahasiswa dalam memahami materi pokok yang akan dipelajari. Hal ini dikarenakan ada bagian-bagian tertentu dari pengetahuan awal mahasiswa yang muncul dari materi pokok. Apresiasi matematika, yaitu untuk memiliki kemampuan pemecahan masalah dalam pemahaman konsep ini memang sangat sulit untuk dilakukan, namun hal ini tidak akan sulit dilakukan jika apresiasi matematika tumbuh dalam diri mahasiswa. Adapun maksud dari kecerdasan logis adalah dalam memecahkan masalah yang berkaitan dengan pemahaman konsep terdapat empat langkah atau fase yang harus dilakukan oleh mahasiswa itu sendiri diantaranya memahami masalah terlebih dahulu, melaksanakan rencana, dan mengecek kembali hasil penyelesaian yang telah dilakukan mahasiswa tersebut.

Hal ini menunjukkan bahwa pada mahasiswa Jurusan Pendidikan Matematika UIN Alauddin Makassar angkatan 2016 setelah dilakukan analisis secara keseluruhan mulai dari tes diagnostik dan tes wawancara maka mahasiswa tergolong dalam kategori cukup mampu dalam kemampuan pemahaman konsep pada mata kuliah aljabar linear elementer. Meskipun masih ada beberapa dari mahasiswa yang berada pada kategori tidak mampu dalam menjawab tes/soal ujian yang diberikan tentang pemahaman kemampuan matematis dalam menyelesaikan soal aljabar linear elementer, namun ada sebagian dari mahasiswa yang masih bisa termasuk dalam kategori cukup mampu bahkan kategori mampu. Hanya saja, seringkali mahasiswa sudah mulai lupa dengan konsep yang akan diterapkannya, terlebih ketika materinya sudah lama berlalu. 


\section{SIMPULAN}

Berdasarkan hasil tes diagnostik, kemampuan pemahaman mahasiswa jurusan pendidikan matematika UIN Alauddin Makassar angkatan 2016 dalam menyelesaikan soal aljabar linear elementer pada konsep ruang vektor, subruang vektor, dan ruang vektor Euclidean jika ditinjau dari indikator kemampuan pemahaman matematis, mahasiswa tergolong cukup mampu pada indikator: (1) pemahaman mampu menyatakan ulang sebuah konsep, (2) menyajikan konsep dalam berbagai bentuk representasi matematika, (3) menggunakan, memanfaatkan dan memilih prosedur tertentu, dan (4) mengaplikasikan konsep/algoritma ke pemecahan masalah. Namun, mahasiswa tergolong tidak mampu pada indikator kemampuan memberi contoh dan bukan contoh. Hal tersebut berdasarkan hasil analisis data yang dilakukan secara keseluruhan, sehingga persentase ketercapaian mahasiswa berada pada kategori cukup mampu. Berdasarkan hasil wawancara dengan lima subjek yang dipih berdasarkan kategori mampu, cukup mampu dan tidak mampu, diperoleh pada mahasiswa yang tergolong mampu dapat memenuhi sebagian besar indikator kemampuan pemahaman, sedangkan pada mahasiswa yang tergolong cukup mampu masih memiliki kendala dalam menuangkan atau menggunakan konsep yang diketahui ke dalam soal/permasalahan. Dan pada mahasiswa yang yang tergolong tidak mampu memiliki kendala dalam memahami konsep-konsep terkait materi ruang vektor, sub ruang vektor dan vektor Euclidean. Adapun faktor-faktor yang mempengaruhi pemahaman konsep mahasiswa pendidikan matematika UIN Alauddin Makassar angkatan 2016 pada mata kuliah Aljabar Linear Elementer dalam konsep ruang vektor, sub ruang vektor, dan ruang vektor Euclidean, yaitu faktor internal: kurangnya minat belajar, kurang fokus dalam belajar, motivasi belajar rendah, konsentrasi belajar rendah, kemampuan mengingat rendah, dan kurang rasa percaya diri. Faktor eksternal, yaitu mahasiswa kurang memahami maksud soal, mahasiswa lupa konsep aksioma, mahasiswa tidak tahu konsep aksioma, penggunaan gadget selama proses pembelajaran, dosen kurang memperhatika mahasiswa selama proses pembelajaran, dan tidak adanya buku pegangan mahasiswa.

\section{DAFTAR PUSTAKA}

Darminto, B. P. (2009). Upaya Peningkatan Pemahaman Konsep Aljabar dan Sikap Mahasiswa Calon Guru Matematika terhadap Pembelajaran Berbasis Komputer. Kontribusi Aljabar Dalam Upaya Meningkatkan Kualitas Penelitian Dan Pembelajaran Matematika Untuk Mencapai Word Class University. Yogyakarta: Seminar Nasional Aljabar, Pengajaran dan Terapan.

Fitria, M., Arnawa, M., \& Lufri. (2014). Pengembangan Modul Aljabar Linear Elementer Bernuansa Konstruktivisme Berbantuan ICT. Jurnal Eksakta, 1, 34-42.

Hadiwiyanti, I. (2015). Analisis Pemahaman Konsep Fisika Siswa SMP dan Penerapannya di Lingkungan Sekitar. Universitas Negeri Semarang.

Nursuprianah, I., \& Sholikhah, M. (2009). Analisis Kesulitan Mahasiswa Dalam Memahami Mata Kuliah Aljabar Matriks (Studi Kasus Pada Semester IV Tadris Matematika Tahun Akademik 2008/2009 Di STAIN Cirebon). EduMa, 1(1), 75-85.

Rosita, C., Laelasari, \& Noto, M. (2014). Analisis Kemampuan Pemahaman Matematis Mahasiswa pada Mata Kuliah Aljabar Linear 1. Jurnal Euclid, 1(1). 
Sanuartini. (2000). Pengaruh Kreativitas Belajar Matematika Terhadap Prestasi Belajar Matematika. Universitas Negeri Makassar.

Sudijono, A. (2009). Statistik Pendidikan. Jakarta: PT Raja Grafindo Persada.

Sugiyono. (2013). Metode Penelitian Pendidikan Pendekatan Kuantitatif, Kualitatif, dan $R \& D$. Bandung: Alfabeta.

Sumarmo, U. (2006). Pembelajaran Keterampilan Membaca Matematika pada Siswa Menengah. Bandung: Makalah disajikan dalam seminar nasional FPMIPA UPI. 
